\title{
Forgotten Piano Music of Karl Goldmark
}

\section{Tihamér Hlavacsek}

I began researching Goldmark's piano music in 2005 as part of a recording project for Hungaroton (the Hungarian recording company). Hungaroton's primary aim was to (re)discover and premiere repertoire that had not been recorded before. My attention was drawn to the composer's oeuvre by my former professor at Yale School of Music, Peter Frankl. Whilst a number of Goldmark's works had been available on recordings by renowned artists - Die Königin von Saba, Violin Concerto, chamber music, songs - almost none of his piano works had been released before. ${ }^{1}$ I was contracted to record Goldmark's complete works for piano for Hungaroton, as a "world premiere" edition, containing the solo piano pieces and four-hand works, as well as a number of the composer's original arrangements of his other works for piano solo and piano four-hands. ${ }^{2}$

Since 2015, I have continued to pursue my research of Goldmark's piano music in the doctoral programme at Royal College of Music, London. The main aim of my research is to place Goldmark's piano works within the context of $19^{\text {th }}$ - and early $20^{\text {th }}$-century Vienna and, in a broader sense, within Romantic piano literature. I approach this from two perspectives: by a stylistic identification of the music and by examination of performance history and reception of the repertoire. This investigation will enhance our understanding of Goldmark's piano style. Placing his piano works in the context of $19^{\text {th }}$ - and early $20^{\text {th }}$-century Viennese musical life will increase awareness of this repertoire amongst musicians and audiences, enabling them to relate it to contemporary music literature.

This article aims to provide an introduction to Goldmark's piano music and to its context by exploring existing scholarship on him and by identifying some of the key stylistic features in his complex musical language.

\footnotetext{
${ }^{1}$ Karl Goldmark, Violin Concerto Op.28, Itzhak Perlman, EMI, 2008, CD; Nathan Milstein, EMI, 1957, LP; Joshua Bell, Sony, 2000, CD. Karl Goldmark, Die Königin von Saba Op.27, Adam Fischer, Hungaroton, 1980, LP. Karl Goldmark, Merlin, Gerd Schaller, BR Klassik, 2009, CD. Karl Goldmark, Complete works for violin and piano, Ulf Wallin, Bruno Canino, CPO, 2000, CD; among others.

2 Karl Goldmark, Works for Piano (Complete) Vol. 1-4, Tihamér Hlavacsek, Hungaroton Classic, vol. 1, HCD 32387, 2005; vol. 2, HCD 32493, 2006-2007; vol. 3, HCD 32612, 2009; vol. 4 (piano duets with Balázs Szokolay), HCD 32673, 2011-2012. 4 CDs.
} 


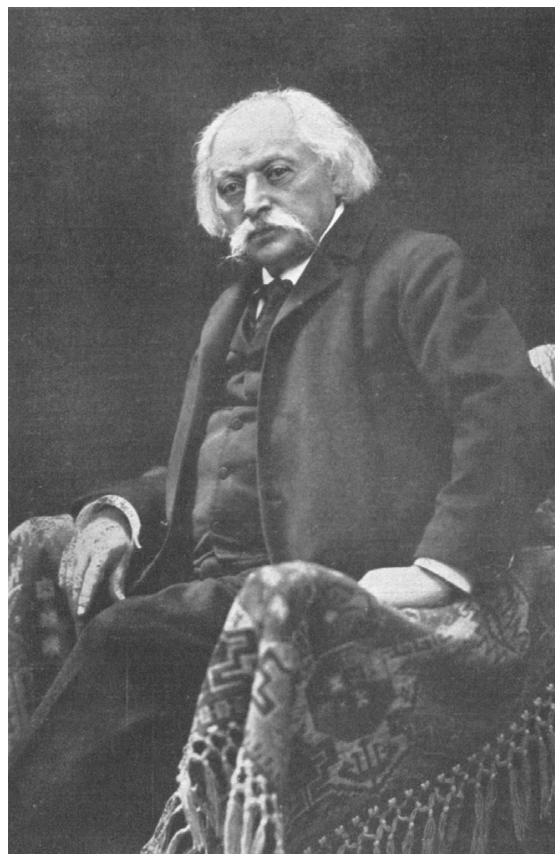

Karl Goldmark; from the private collection of Dr Thomas Aigner, head librarian, Wiener Stadtbibliothek

\section{Goldmark in existing literature}

Goldmark was born in Hungary and spent his childhood and youth there. ${ }^{3} \mathrm{He}$ later moved to Vienna where he settled for the rest of his life, nevertheless making frequent visits to Budapest, especially after the 1870s. Goldmark achieved his first real success in Vienna as a composer, and won Eduard Hanslick's appreciation with his Sakuntala overture (1865) but it was the premiere of his opera The Queen of Sheba (1875) that marked a breakthrough and launched his international career. ${ }^{4}$

Contemporary sources, especially from early 1900s, present Goldmark as an important figure, occupying a prestigious place in the musical life of Vienna alongside Brahms and Hanslick, and also enjoying international renown. Harald Graf discusses Goldmark's relation to personalities of $19^{\text {th }}$-century Vienna's

${ }^{3}$ Karl Goldmark, Emlékek életemböl [Recollections from My Life], ed. and transl. Kecskeméti István, (Budapest: Zenemúkiadó Vállalat, 1980), 5-11.

${ }^{4}$ David Brodbeck, "Poison-Flaming Flowers from the Orient and Nightingales from Bayreuth. On Hanslick's Reception of the Music of Goldmark," in Rethinking Hanslick: Music, Formalism, and Expression, eds. Nicole Grimes, Siobhán Donovan and Wolfgang Marx (Rochester NY: University of Rochester Press, 2013), 136-139. 
musical life and provides insight into his contemporary reception. ${ }^{5}$ The contemporary scholar, Fuller Maitland described Goldmark as the best composer for the stage, working in Germany [sic], stating that "he has his distinguished place of his own among contemporary musicians". ${ }^{6}$ The Brahms-biographer Max Kalbeck referred to Goldmark as a "European celebrity", Julius Korngold wrote about a "Goldmark-cult" in 1915 and Karl Kraus considered him "the greatest living music-drama composer since Wagner's death." Thus in his lifetime, Goldmark appeared to be "one of the [Austro-Hungarian] monarchy's most prominent representatives", celebrated as the most famous Hungarian-born composer after Liszt and a national hero by Hungarians. ${ }^{8}$

The Viennese critic Eduard Hanslick played an important role in Goldmark's career and in bringing the young composer's music to public attention, as David Brodbeck has investigated in detail. ${ }^{9}$ Although, like Goldmark, Hanslick had migrated to Vienna from an Eastern region of the monarchy, nevertheless his writings were capable of shaping his subjects' careers. ${ }^{10}$ As Hanslick indicated: "the first half of his [Goldmark's] journey was difficult and troublesome" however, later both Hanslick and Goldmark became pillars of Viennese musical establishment. ${ }^{11} \mathrm{He}$ recognized the distinctive qualities of Goldmark's music

5 Harald Graf, “Carl Goldmark. Beziehung zu den Zeitgenossen,” [Karl Goldmark. Relation to his Contemporaries] Studia Musicologica Academiae Scientiarum Hungaricae 38 (1997): 371-407.

${ }^{6}$ J. A. Fuller Maitland, "Carl Goldmark," in Masters of German Music (London: Osgood, McIlvaine \& Co, 1894): 169.

7 Kalbeck referred to Goldmark as "europäische Zelebrität" [European celebrity] in his landmark biography of Johannes Brahms. Max Kalbeck, Johannes Brahms, vol. 3 (Berlin: Deutsche BrahmsGesellschaft, 1913), 132; Julius Korngold, "Goldmark-Kultus” Neue Freie Presse (January 5, 1915); "seit Richard Wagners Tod der größte lebende Musikdramatiker geworden zu sein.” Graf, "Goldmark - Beziehung zu den Zeitgenossen,” 372.

8 Gerald Schlag, "Geleitwort" [Preface] to Carl Goldmark (1830-1915): Opernkomponist der Donaumonarchie. Ausstellung des Burgenländlischen Ländesmuseums [Exhibition of the Ländesmuseum of Burgenland], ed. Nóra Wellmann (Eisenstadt: Burgenlandische Ländesmuseen, 1996); Gerhard J. Winkler, "Carl Goldmark: Ein biographischer Abriß” in Carl Goldmark (1830-1915): Opernkomponist der Donaumonarchie. Ausstellung des Burgenländlischen Ländesmuseums [Exhibition of the Ländesmuseum of Burgenland]. Edited by Nóra Wellmann (Eisenstadt: Burgenlandische Ländesmuseen, 1996), 15-19.; On Goldmark's reception since his death and some of its Hungarian aspects see: Kecskeméti István, “Goldmark Károly recepciói. Visszatekintés halálának 75. évfordulóján." [Karl Goldmark's Receptions. Retrospection on the $75^{\text {th }}$ Anniversary of his Death] Muzsika 32, no. 12 (December 1989): 33-37.

9 Brodbeck, "Poison-Flaming Flowers," 135.

${ }^{10}$ Lauren Freede, “The Critic as a Subject. Hanslick's Aus meinem Leben as a Reflection on Culture and Identity," in Retbinking Hanslick: Music, Formalism, and Expression, eds. Nicole Grimes, Siobhán Donovan and Wolfgang Marx (Rochester NY: University of Rochester Press, 2013): 187-211.

${ }^{11}$ Eduard Hanslick, “Karl Goldmark (Zum 18. Mai 1900)," Neue Freie Presse (May 18, 1900): 1-2. 
in his earlier works as: “...powerful and singular...” and “...undeniable proof of talent...". ${ }^{12}$ Despite Hanslick's positive assessments of Goldmark's earlier compositional work, (especially the Sakuntala overture), he had mixed feelings after the premiere of Die Königin von Saba, mainly due to its prevailing oriental colour, which prevented him from perceiving Goldmark's music as fully "German" and therefore "would forever inhibit a full-throated approval of his friend's music". ${ }^{13}$

Bertagnolli, exploring Goldmark's place in Viennese musical circles, positions him along Wagner and Brahms. Goldmark advocated Wagnerian views in his early writings, however, later took sides with Brahms. Later in his life his views became more moderate, settling somewhere between the two extremes. ${ }^{14}$ Bertagnolli also offers a fairly pertinent summary of Goldmark's style: "He imitated Mendelssohn and revered Brahms but assimilated Wagnerian techniques; and his scores disclose traces of the synagogue's liturgy, Hungarian popular and folk idioms, and, in his later years, Impressionism." ${ }^{15}$

István Kecskeméti, a musicologist who specialized on Goldmark, pointed out that the popularity of Goldmark's music reached its peak at the end of $19^{\text {th }}$ century. ${ }^{16}$ Despite the international renown Goldmark enjoyed especially after the premiere of Die Königin von Saba in Vienna in 1875, and the fact that his works were frequently performed in Vienna, Pest and in other cities in Europe and America during his life, his music seems to disappear from concert programmes after the 1930s, remaining overlooked until the very end of the $20^{\text {th }}$ century. ${ }^{17} \mathrm{Die}$ Königin von Saba had stayed in the repertoire of the Vienna Hofoper almost until the Anschluß, but then his works disappeared from concert halls and operas. ${ }^{18}$

12 “...ein starkes und eigentümliches...”Eduard Hanslick, "Musikalische Stazionen” in Der 'Modernen Oper' vol. 2 (Berlin: Allgemeiner Verein für Deutsche Literatur, 1901), 301; “... unleugbar Beweise eines Talentes...” Eduard Hanslick, “Musik” Die Presse (January 17, 1861): 2.

13 Brodbeck, "Poison-Flaming Flowers," 134.

${ }_{14}$ Paul A. Bertagnolli, "Conservativism Assimilates the Prometheus Myth: Concert Overtures by Bargiel and Goldmark," in Prometheus in Music. Representations of the Myth in the Romantic Era (Burlington VT: Ashgate Publishing Company, 2007): 316, 321.

15 Ibid, 317.

${ }^{16}$ István Kecskeméti was a Hungarian musicologist, Goldmark-specialist. He prepared Hungarian translation of Goldmark's recollections Erinnerungen aus meinem Leben [Memories from my Life] (1922) and published several articles on the composer eg. "Goldmarkiana. Ismeretlen primer források Magyarországon. [Goldmarkiana. Unknown Primary Sources in Hungary],” Muzsika 42, no. 4 (April 1999): 18-23; "Goldmark Károly recepciói. Visszatekintés halálának 75. évfordulóján,” [Carl Goldmark's Receptions. Retrospection on the 75th Anniversary of his Death] Muzsika 32, no. 12 (December 1989): 33-37; and a series of lectures on Goldmark's music, Hungarian Radio, Budapest, 1980.

17 Kecskeméti, “Receptions,” 33.

${ }_{18}$ Possible historical and societal reasons for this would constitute a subject for further study but it would well exceed the scope of my research. 
The fact that Goldmark's music was rarely performed after Second World War may explain why he is neglected almost entirely in more recent scholarship, especially in general histories of Romantic music. When Goldmark is mentioned it is typically only a reference to his best-known works, primarily to Die Königin von Saba.

Dahlhaus refers to Goldmark's opera in Nineteenth-Century Music - alongside works by Gounod, Bizet or Massenet - when discussing $19^{\text {th }}$-century exoticism and orientalism. ${ }^{19} \mathrm{He}$ argues in his article Neo Romanticism that the second half of $19^{\text {th }}$ century has not been easily accessible in terms of 'musico-historical outlines' and that knowledge of such figures as Bruch or Goldmark is "all too slight and fragmentary". As a possible, but not exclusive reason for that, he adds: "The history of music in the nineteenth century [...] is still seen primarily as the history of its heroes - the 'great masters,' the composers of the works which constitute the "canon."'20

While Taruskin also refers to Goldmark tangentially, admitting that he was "Vienna's leading opera composer at the turn of the century", Rosen - very surprisingly - does not even mention his name when surveying romantic opera repertoire in his Romantic Generation despite referring to such figures as Méhul or Meyerbeer, to whose operatic style Goldmark is often compared. ${ }^{21}$

Thus scholarship seems to mirror the absence of Goldmark's works from performances after 1930s; posthumous scholarship gathered mainly around Goldmark-anniversaries in 1930 and $1980 .{ }^{22}$ However, a "renaissance" of his music can be sensed today through re-staging his opera, Die Königin von Saba in Budapest in 2015, recording projects of Hungaroton, CPO, SWR, BR Klassik and other labels, covering instrumental, chamber and vocal works as well as an increasing number of concert performances of Goldmark's works. ${ }^{23}$ International musicological conferences and concerts were organized on the $100^{\text {th }}$ anniversary of his death (2015) in Vienna and Budapest, as well as a year-long concert cycle featuring his works by Hungarian Radio. An International Goldmark Society was founded in Berlin in the same year, collecting data on publications and

${ }^{19}$ Carl Dahlhaus, Nineteenth-Century Music, transl. J. Bradford Robinson (University of California Press, Berkeley and Los Angeles, California, 1989), 303-304.

${ }^{20}$ Carl Dahlhaus, "Neo-Romanticism," transl. Mary Whittall, 19th-Century Music 3, no. 2 (November 1979): 97-105.

${ }^{21}$ Richard Taruskin, "Music in the Early Twentieth Century," in Oxford History of Western Music, vol. 4. (Oxford: Oxford University Press, 2010);

https://www.oxfordwesternmusic.com/view/Volume4/actrade-9780195384840-div1-011002. xml?rskey=rL6OKI\&result=1 (accessed March 2, 2017); Charles Rosen, The Romantic Generation (Cambridge, Massachusetts: Harvard University Press, 1995), 604, 639-640.

${ }^{22}$ Kecskeméti, “Receptions,” 34.

${ }^{23}$ Ibid.; Die Königin von Saba was performed at Margit-sziget, and Erkel theatre in Budapest in 2015. 
performances of Goldmark and Musikverlag Hoeflich is reissuing scores of the composer's works. ${ }^{24}$ Scholarly interest in the composer has grown markedly in late $20^{\text {th }}$ - early $21^{\text {st }}$ century, and continues to do so, as indicated in studies by Graf, Brodbeck, Bertagnolli and Hofer among others. ${ }^{25}$

\section{Goldmark's piano music}

Whilst Goldmark's most popular works remained in orchestral concert repertoire for decades after his death, it is less well known that he composed a considerable number of piano works throughout his career. This repertoire is virtually unknown still today, even amongst musicians. Very few pianists seem to know of the existence of Goldmark's piano works and even fewer perform any of them.

Whilst several studies discuss Goldmark's life and music in general and his main works, the operas, there is almost no literature on his piano works. ${ }^{26}$ Even their existence is sparingly indicated in the scholarship on Goldmark. None of the available sources on Goldmark, including the latest New Grove Dictionary of Music and Musicians and Musik in Geschichte und Gegenwart list all his piano pieces. ${ }^{27}$ The Cambridge Companion to the Piano does not refer to Goldmark at all when surveying nineteenth century piano repertoire. Furthermore, the anthology of Hungarian composers, which does have a Goldmark chapter, does not mention any of his piano works. ${ }^{28}$ Only two studies list some of Goldmark's piano works, adding only general comments on some of the pieces but their discussion

${ }^{24}$ Jürgen Hoeflich, "Musikproduktion Hoeflich," Complete Catalogue, accessed March 2, 2017, https://repertoire-explorer.musikmph.de/en/catalogue-list-view

25 Graf, "Carl Goldmark - Beziehung," 1997; Brodbeck, "Poison-Flaming Flowers," 2013; Bertagnolli, “Conservativism,” 2007; Johann Hofer, Carl Goldmark Komponist der Ringstraßenzeit (Vienna: Edition Steinbauer GmBH, 2015).

${ }^{26}$ See Kálmán Mária, Goldmark Károly 1830-1930: Adalékok életéhez és múveihez Magyar vonatkozásban [Karl Goldmark 1830-1930: Additions to his Life and Works in Hungarian Context] (Budapest: Sárkány Nyomda Részvénytársaság, 1930); Hammerschlag János, “Goldmark az európai zenében” [Goldmark in European Music], Muzsika 2, no. 4-5 (1930): 144-145; Káldor Márton and Várnai Péter, Goldmark Károly élete és müvészete [Life and Art of Karl Goldmark] (Budapest: Mưvelt Nép Tudományos és Ismeretterjesztő Kiadó, 1956); Fuller Maitland, “Carl Goldmark,” 1894; Bertagnolli, "Conservativism," 2007.

${ }^{27}$ Wilhelm Pfannkuch and Gerhard J. Winkler, "Goldmark, Karl." Grove Music online. Oxford University Press, accessed January 30, 2013, http://www.oxfordmusiconline.com/subscriber/article/ grove/music/11384; Gerhard J. Winkler, “Goldmark, Karl, Carl, Károly”, Die Musik in Geschichte und Gegenwart ed. Ludwig Finscher. Vol. 7, Personenteil. (Basel: Bärenreiter, 2007). Print: 12391243.

${ }^{28}$ David Rowland, The Cambridge Companion to the Piano (Cambridge: Cambridge University Press, 1998); Frideczky Frigyes, “Goldmark Károly,” in Magyar zeneszerzốk [Hungarian Composers] (Budapest: Athenaeum Kiadó, 2000), 36. 
is limited. ${ }^{29}$ Although Kálmán offers a more detailed description of Goldmark's life and main works, presentation of the piano works is limited to mentioning the titles of the piano pieces, as the author focusses primarily on reception. A more recent article by Mária Eckhardt discusses folk-like melodies in some of Goldmark's works, intended "Hungarian" by the composer, Aus Jugendtagen, Zrínyi symphonic poems and Magyar ábránd, a substantial work for piano. ${ }^{30}$

Goldmark composed more than 50 pieces for piano solo and four hands, from his youth (e.g. Sturm und Drang, 1858) through his mature (e.g. Novellettes, 1870s) and late (e.g. Characterstücke, 1903-1909) years. This clearly indicates his strong interest in one of the most significant instruments of the Romantic era, which played an important role in his life and compositional practice. At the height of his career, after the successes of the Die Königin von Saba (Op.27, 1875), the Ländliche Hochzeit (Op.26, 1876) and the Violin concerto (Op.28, 1877), Goldmark turned again to the piano with a set of four pieces (two Novellettes, a Preludium and Fugue Op.29) in 1877. The majority of his piano works are from his latter years, especially from the early 1900s, when Goldmark, as a celebrated artist, returned to composing piano pieces to express his distilled and somewhat retrospective thoughts. ${ }^{31}$ The Characterstücke and Georginen and a number of unpublished piano pieces - which might originally have been intended to be part of one of these sets - are from his late years. Table 1 shows the distribution of Goldmark's piano works throughout his career, interspersed with major symphonic and operatic works. Piano works are shown in bold type in the table.

\begin{tabular}{lc}
\hline \multicolumn{1}{c}{ WORK } & YEAR \\
\hline Sturm und Drang Op. 5 (set of piano 9 pieces) & 1858 \\
Drei stücke (set of 3 piano pieces) & 1858 \\
Sakuntala (overture) & 1865 \\
The Queen of Sheba & 1875 \\
Ländliche Hochzeit (symphony) & 1876 \\
Violin concerto & 1877 \\
Op.29 (piano pieces: Novellettes, Preludium and Fugue) & 1877 \\
Merlin & 1885 \\
Magyar ábránd [Hungarian fantasy] & 1885 \\
Das Heimchen am Herd & 1895 \\
Götz von Berlichingen & 1902 \\
Characterstücke (set of piano 8 pieces) & $1903-1909$ \\
Wintermärchen & 1907 \\
Georginen Op.52 (set of 6 piano pieces) & 1909 \\
Individual piano pieces & $1903,1909,1913$ \\
\hline
\end{tabular}

Table 1. Years of composition of Goldmark's major symphonic and piano works

${ }^{29}$ Kálmán Mária, Goldmark Károly, 1930; Káldor-Várnai, Goldmark Károly élete és müvészete, 1956.

${ }^{30}$ Mária P. Eckhardt, "Einflüsse der ungarischen Musik bei Goldmark [Influences of Hungarian Music on Goldmark]”, in Vienna Brabms congress, 1983, eds. Biba, Otto and Antonicek, Susanne (Tutzing: Hans Schneider, 1988), 427-436.

${ }^{31}$ István Kecskeméti, (lectures on Goldmark’s music) Hungarian Radio, Budapest, 1980. 
Goldmark's piano works include large-scale sets comprised of character pieces (e.g. Sturm und Drang, Characterstücke or Georginen) and individual pieces (e.g. Novellette, Magyar ábránd [Hungarian fantasy] among others) as well as original four-hand compositions (e.g. Three pieces, Dances) and the composer's transcriptions of his own symphonic works for piano (e.g. Sakuntala overture). Goldmark originally trained as a violinist and he played in theatre orchestras in Sopron and Vienna in his youth. According to his memoirs, he was a self-taught pianist (and also an autodidactic composer). ${ }^{32}$ Nevertheless, he gave piano lessons in Pest and later in Vienna to support himself. One of his pupils, Caroline Bettelheim, became an outstanding pianist and celebrated singer at Hofoper, Vienna. ${ }^{33}$ She premiered some of Goldmark's piano pieces in Vienna. ${ }^{34}$

For the sake of the recording cycle, I had to come to a definition regarding what constituted a piano work. Together with Hungaroton's artistic director, I had to make decisions about what to include in the "complete" recordings. As no published source lists Goldmark's works for piano completely, a definitive list of his piano works did not exist. István Kecskeméti's list of works is the most detailed amongst existing ones, containing almost all the printed and the unpublished works. ${ }^{35}$ Kecskeméti worked with a fairly obvious concept of what constituted a "piano work"; fully written out works, dated and signed by Goldmark, the majority with a title in the composer's hand. However, Goldmark's sketchbooks contain a number of canons and fugues that he did not list. Many of them were worked out in great detail and completely written out, some even signed and dated. Nevertheless, a number of questions arose as to whether they should be considered piano pieces. In some cases, it was not clear from the notation whether a piece was actually intended to be a piano work. Some were notated in four staves, which suggested that they might be vocal works, although without any indication of a text. With others, spread over two staves, the span of the voices did not make the setting seem reasonable for the piano. Furthermore, no instrumentation was indicated on them. We also know from Goldmark's recollections that he composed a great number of fugues, almost daily, to develop his compositional skills, although he burned many of them. ${ }^{36}$ Therefore the question emerged as whether Goldmark intended the fugues and canons in the sketchbooks as works to be performed or whether they belonged to his exercises (and escaped burning) and therefore should not count as piano works.

32 Goldmark, Emlékek életembôl, 17, 50-51.

33 Brodbeck, "Poison-Flaming Flowers," 137.

34 Ibid, 135.

35 Goldmark, Emlékek életemböl, 182-185.

${ }^{36}$ Ibid, 50-51. 
Having considered all these issues, we finally decided not to include the canons and fugues in the list of Goldmark's piano works. The two fugues (in A minor and in $\mathrm{F}$ minor), included in the complete recordings are amongst those listed as unpublished works by Kecskeméti. They can be found as individual pieces in manuscripts in the archives of National Széchényi Library in Budapest. Their setting leaves no doubt that they were intended as piano works. However, we did not include any canons and fugues from Goldmark's sketchbooks in the recordings.

In Goldmark's time composers often prepared arrangements of their own symphonic works for the piano in different settings (for two-hands, four-hands, eight hands or two pianos, etc.) with the purpose of familiarization of their works with the public.$^{37}$ In that time, music lovers often gathered to read works of current or older music literature at the piano as well as to make chamber music. ${ }^{38}$ Goldmark was no exception; he made piano versions of his symphonic - such as Sakuntala - and operatic works. As mentioned earlier, after the premiere of his first opera, Die Königin von Saba, Goldmark became a celebrity. This might well have inspired the production of arrangements of his "most famous" works, not only by him but by other transcribers as well. The number of such arrangements for the piano is remarkable: many of his operas - some of them in their entirety, the Rustic Wedding symphony and other symphonic works were available in different settings for the piano. When making my recordings, only those transcriptions came into consideration which were made by Goldmark himself. In many cases this was clear, as the arranger's name or the phrase "vom Komponisten" (from the composer) was indicated on the printed score. Those works prepared by others were ignored.

However, even in the case of those arrangements where the authorship could be clarified, the question of whether those would count as "piano pieces" still remains, as transcriptions were prepared primarily for use at the home in that era, not for concert performances. ${ }^{39}$ Nevertheless, it is difficult to draw strict lines in this respect as some of the transcriptions would work well as concert pieces. One should also differentiate between those which follow the original work note-to-note, and those having changes in them, as the latter would more likely

${ }^{37}$ I use the term "arrangement" for a certain work being applied for a different medium (instrument), while "transcription" refers to elaboration of a piece with significant changes made to the original. Grove Music Online, Oxford Music Online, "Arrangement," accessed October 1, 2017,

http://www.oxfordmusiconline.com/subscriber/article/grove/music/01332?q=arrangement\&search=quick\&source=omo_gmo\&pos=1\&_start=1\#firsthit

${ }^{38}$ Katy Hamilton and Natasha Loges, "Brahms in the Home: An Introduction," 5-7, 10-12; Michael Struck, "Main and shadowy existence(s): Works and arrangements in the oeuvre of Johannes Brahms," in Brahms in the Home and the Concert Hall: Between Private and Public Performance, eds. Katy Hamilton and Natasha Loges (Cambridge, UK: Cambridge University Press, 2014), 121.

39 Struck, "Main and shadowy existence(s)", 95-97. 
qualify for being a piano work, if prepared by the composer. Having considered those issues we came to a decision of including only those transcriptions in the list of piano works which were composed unquestionably by Goldmark and for which the piano version was different from the symphonic original. However, we also included a few additional 4-hand transcriptions of Goldmark's works in the recordings (such as parts from Die Königin von Saba) which, to the best of our knowledge, were made by Goldmark.

\section{Stylistic aspects of Goldmark's piano music}

Goldmark's admiration of Mendelssohn, his self-conducted studies in his youth of Johann Sebastian Bach's music and appreciation of Wagner might well have inspired his piano writing. ${ }^{40}$ The textural transparency and delicate virtuosity in some of his early piano pieces might recall Mendelssohn (Example 1), while the sets of character pieces with their given titles (Sturmnacht, Traumgestalten, Novellette), the powerful, in some cases march-like textures and an abundant
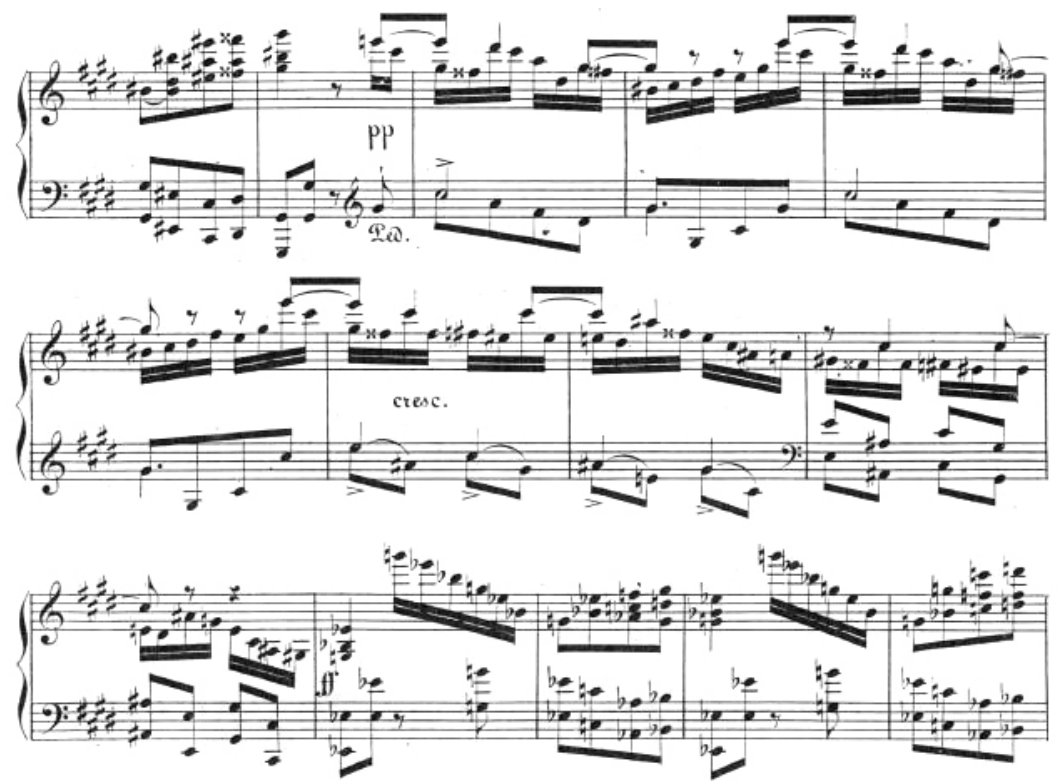

Example 1: Karl Goldmark: Scherzo (Sturm und Drang, No.2) bars 79-91. Transparent and virtuosic piano textures in fast tempo and pianissimo dynamic might allude to Mendelssohn's style.

40 Goldmark, Emlékek életemból, 50-51. 
use of dotted rhythms in some of them remind the listener to the piano style of Schumann (Example 2).
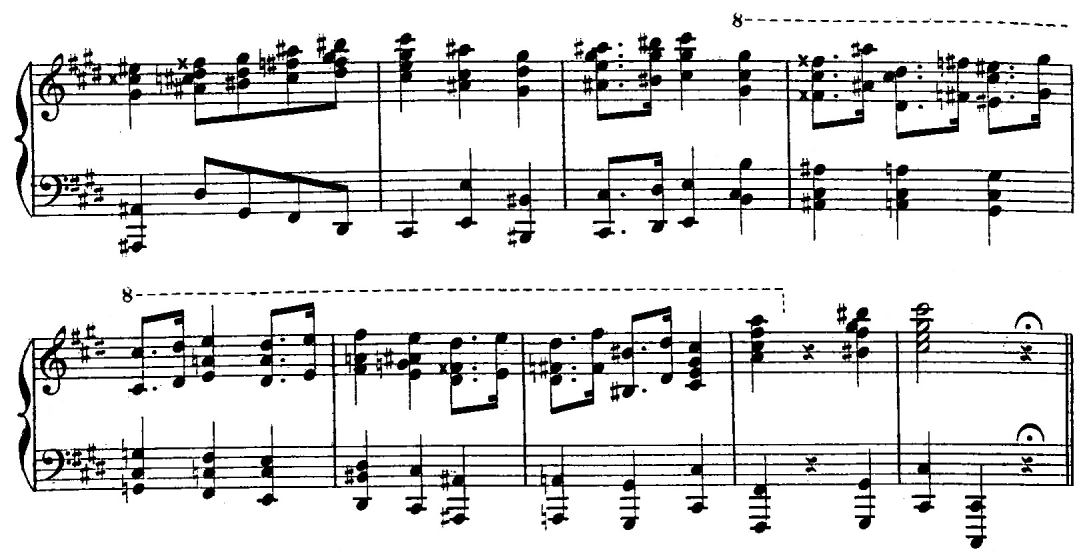

Example 2: Karl Goldmark: Novellette I (Op. 29) bars 68-76. The pulsation of dotted rhythms characterizes the main theme (from bar 2 in the example) and recurs throughout the whole work, alluding to a technique Schumann cultivated in many of his piano pieces.
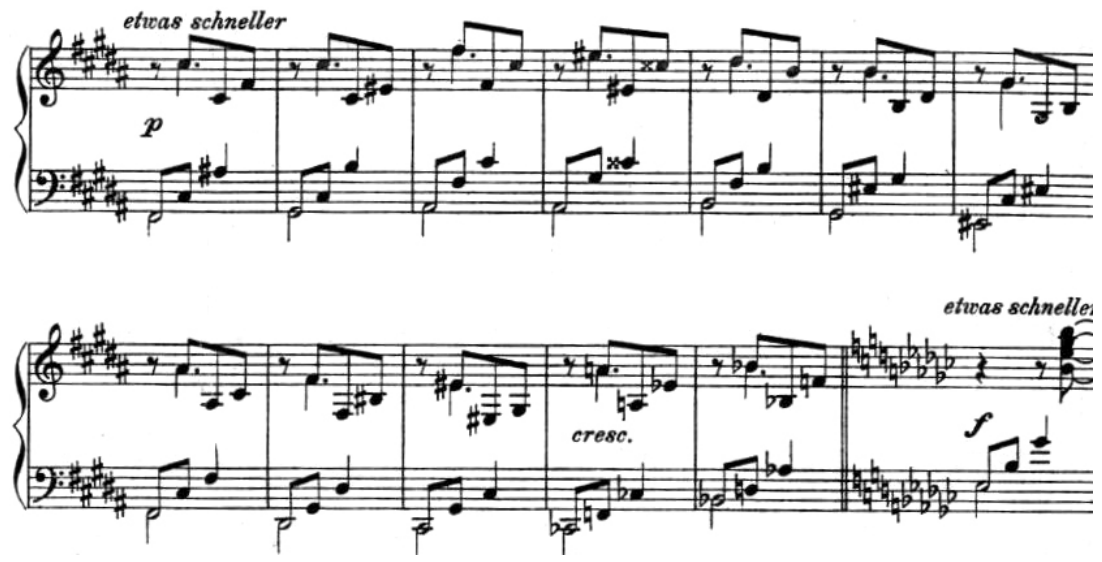

Example 3: Karl Goldmark: Traumgestalten (Characterstücke, No.7) bars 38-50. The musical texture, that the melodic note is the first eight-note of subsequent harmonic groups in the right hand, might also remind to Schumannesque techniques. 
Goldmark's thorough studies of contrapuntal writing made an impact on some of his piano works, culminating in the monumental fugue in $\mathrm{F}$ minor, Op.29 no. 4. (Example 4).
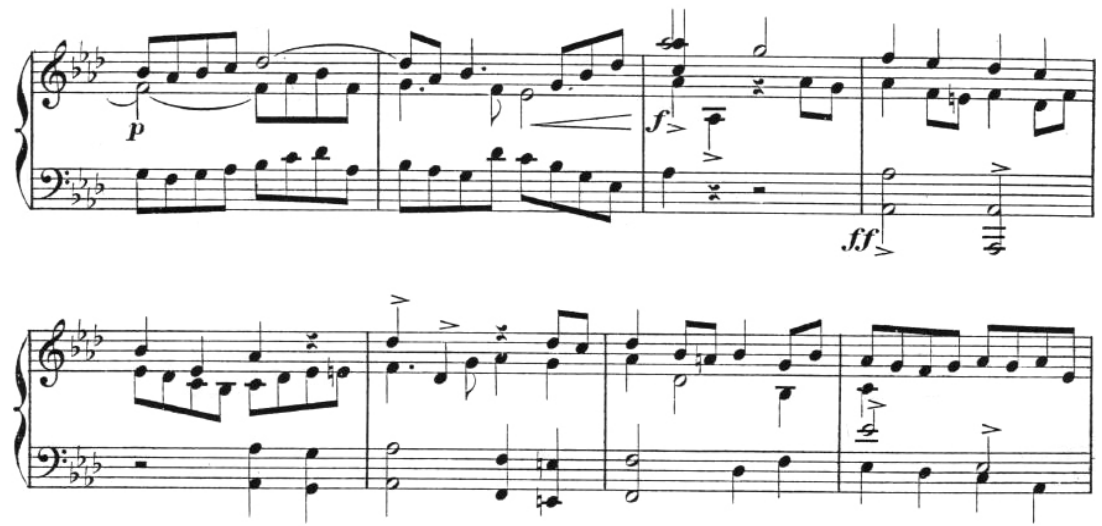

Example 4: Karl Goldmark: Fuge op. 29 no. 4, bars 89-96. The composer deployed techniques of fugal writing in his piano fugue: the following example demonstrates stretto of the themes (the theme-fragment is presented in A-flat major from bar 3 in the example) and augmentation of it in the bass voice (from bar 4 and 8 ).

In his orchestral music Goldmark amalgamates features of a number of different styles and eras, nevertheless creating a unique and individual style by building on them. ${ }^{41}$ Hammerschlag emphasized the complexity and originality of Goldmark's music: "Old and new trends have perceptible influence on him, but [he] never loses himself. All his phrases have natural and original effect at the same time." ${ }^{42}$ In my view, this also applies to his piano music: impact of styles of other (more canonic) composers may be detected in Goldmark's piano music, but at the same time, his musical language possesses a certain originality which is difficult to describe; his music sounds "akin" and "unique" at once.

${ }^{41}$ Bertagnolli, “Conservativism,” 317, 320.

42 "Régi és új irányzatok érezhető hatással vannak reá, de sohasem veszíti el önmagát. Minden frázisa természetesen hat és ugyanakkor eredetinek is” Hammerschlag János, “Goldmark az európai zenében”, 144, 145. 


\section{Areas of my research}

In the following I refer briefly to some of the focuses of my further research of Goldmark's piano music.

Already in Goldmark's lifetime, two nations, the Austrian and the Hungarian claimed him as their "national" composer and this trend became even stronger after his death. ${ }^{43}$ Goldmark was also questioned for his perception of identity and his "Germanness" vs. "Hungarianness" remains a debated topic in the literature on him even today. ${ }^{44}$

According to his own assertion, Goldmark's artistry unfolded primarily through the experience he gained in German-speaking territory. He perceived himself to be a "German composer", which might indicate his cultural assimilation into his "second home country", Austria, where he spent most of his life and gained education - even if it was not consistent - and experience as a musician. Goldmark reflected on his ties to Vienna and his native country:

Well, I have been living in Vienna for 67 years, I gained my knowledge and art from sources of German culture, so I consider myself German in this respect. Besides that, I love my second home country where I became a man and developed, and to which I owe everything I gained. But all that could not tear my strong and deep-rooted feelings towards my native country [Hungary] from my soul. [...] In this respect I remained faithful to my native country. ${ }^{45}$

Goldmark studied the works of J. S. Bach and Beethoven and was an admirer of Mendelssohn in his youth. ${ }^{46}$ After moving to the capital of the Habsburg Empire, he entered Vienna's musical life (both as a critic for Constitutionelle Österreichische Zeitung and a composer), advocating Wagner and later affiliating to Brahms's circle. In order to enable a better understanding of the impact of the musical tradition originated from the German-speaking territory and manifested

${ }^{43}$ David Brodbeck, "Heimat Is Where the Heart Is; or, How Hungarian was Goldmark?" (lecture, Exoticism, Orientalism and National Identity in Musical Theatre. International Musicological Conference on the Centenary of the Death of Karl Goldmark. Budapest, Institute of Musicology, The Hungarian Academy of Sciences, Research Centre for the Humanities, December 11, 2015); Borgó András, “A zeneszerző akit két nemzet vall magáénak. Goldmark-konferencia Bécsben” [The Composer Who Is Claimed by Two Nations. Goldmark Conference in Vienna], Muzsika 58, no. 1 (January 2015); Kecskeméti, “Carl Goldmark’s Receptions,” 35.

${ }_{44}$ Sebestyén,” Goldmark Károly 1830-1930,” 213; Brodbeck, “Heimat Is Where the Heart Is,” 2015.

${ }^{45}$ Goldmark, Emlékek életembôl, 74. “Nos, hatvanhét éve élek Bécsben, német művelődési forrásokból képeztem magam a tudományban és a művészetben, és ebben az értelemben a németekhez is számítom magam. Szeretem is beérésem és kialakulásom e második otthonát, amelynek mindazt köszönhetem, ami vagyok és amit jelentek. De mindez nem oltotta ki a szülőföld iránt érzett erős, mélyen gyökerező érzelmeimet. [...] Ebben az értelemben megơriztem szülőhazámhoz való hưségemet.” ${ }^{46}$ Goldmark, Emlékek életemböl, 50-51. 

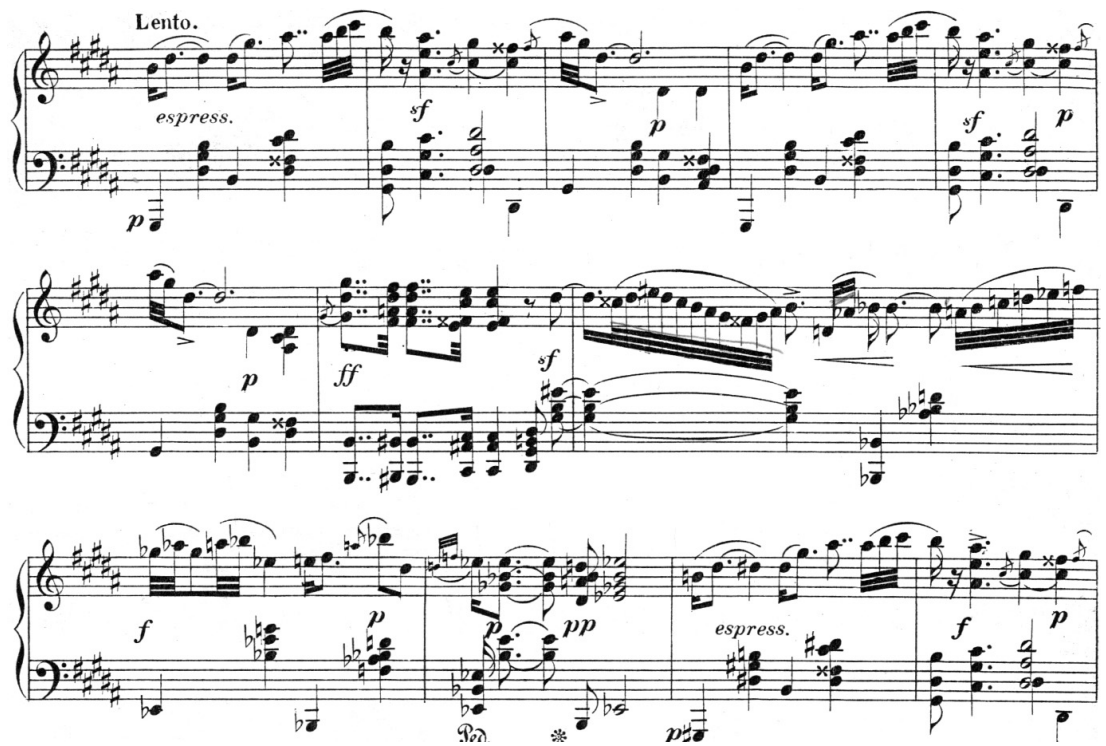

Example 5: Karl Goldmark: Magyar ábránd [Hungarian fantasy] bars 88-95. The melody of the second slow section of the work belongs to the "hallgató" type of nóta. This example also recalls the richly ornamented performance style of the Gypsies of this music.
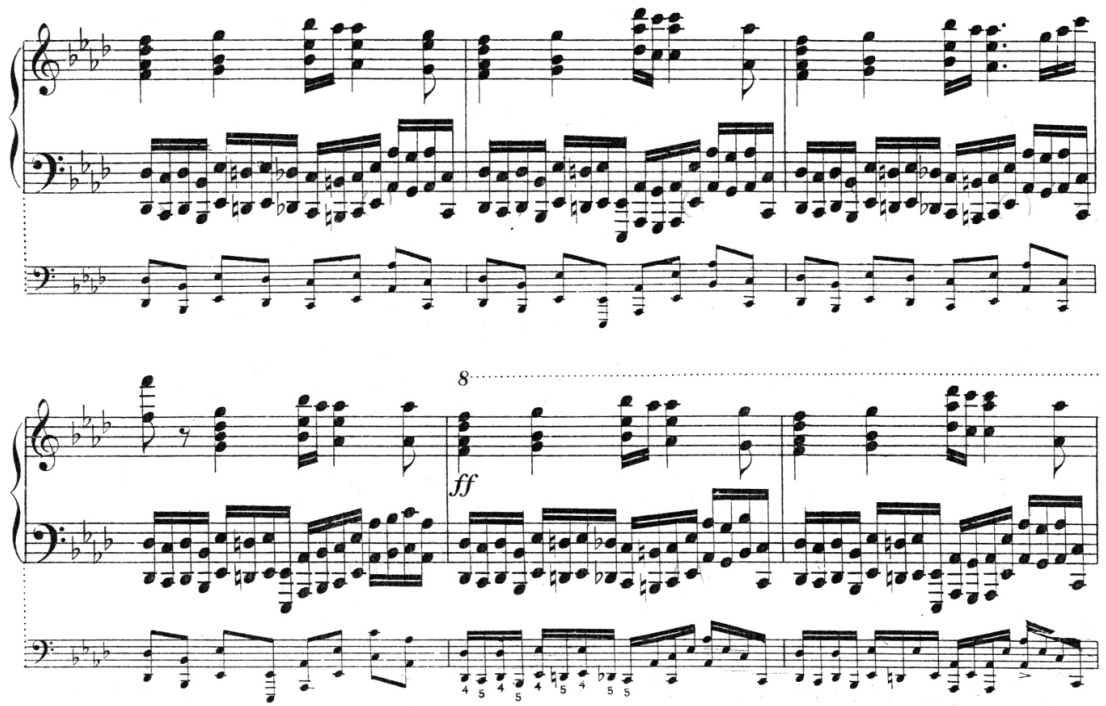

Example 6: Karl Goldmark: Magyar ábránd [Hungarian fantasy] bars 121-126. Goldmark composed csárdás-like (typical Hungarian fast dance in duple meter from the 1850s) music as the closing section of Magyar ábránd. 
in the music of J.S. Bach, Beethoven, Schumann and Brahms among others, on Goldmark's piano style, I examine the extent to which that tradition was decisive in formulating Goldmark's piano style.

Goldmark lived in the territory of the Habsburg Empire and might well have been exposed to "Hungarian" music of that time, either in Hungary or Vienna. ${ }^{47} \mathrm{He}$ composed a few works (e.g. Zrinyi, Aus Jugendtagen - symphonic poems and Magyar ábránd - piano piece) which he intended as "Hungarian", featuring characteristic elements of $19^{\text {th }}$ century Hungarian music - verbunkos and nóta (Example 5). ${ }^{48}$

Although Hungarian influences do not seem to be the most significant in identifying Goldmark's style, they cannot be denied, enriching his complex musical language by adding a characteristic colour to it.

Whether further examples may be found in his piano music, disclosing typical features of music considered "Hungarian" at that time, is part of my exploration, as well as the nature and source of them.

It is well known that Goldmark's symphonic works and operas were permanently present at Vienna's concert programmes and elsewhere in Europe and America in the late $19^{\text {th }}$ and early $20^{\text {th }}$ centuries, but there is almost no data about how much was this true with regard to his piano works. ${ }^{49}$ Preliminary research has already indicated that a number of Goldmark's piano works were performed in Vienna and Pest during his lifetime. He even included a few of his piano compositions in the programmes of his first self-produced concerts in Pest (1859) and in Vienna (1861) which were performed by notable artists of that time. ${ }^{50}$ The importance of exploring how much were these works present amongst Goldmark's compositions in concert programmes in his time and later is that the outcome of this kind of research provides a crucial aspect of understanding the place of the works in the musical scene in Vienna and Pest.

Gaining knowledge through investigation of stylistic features in Goldmark's piano works is not merely essential for the contextualization of the music within Romanticism but it has a considerable practical impact, as well. Identifying certain style traits in the music, their sources, as well as how the composer incorporated them into his works can greatly contribute towards a well-grounded,

\footnotetext{
47 "Hungarian" music (the verbunkos and nóta repertoire) was present not only in Hungary at Goldmark's time but in Vienna, as well, both in performances of travelling Gypsy bands and score editions of songs.

${ }^{48}$ Mária P. Eckhardt, "Einflüsse der ungarischen Musik bei Goldmark," 431-438.

49 Brodbeck, "Poison-Flaming Flowers," 133; Kecskeméti, "Goldmark's Receptions," 33.

${ }^{50}$ Goldmark, Emlékek életemböl, 64; Kálmán Mária, Goldmark Károly 1830-1930: Adalékok életéhez és müveihez Magyar vonatkozásban [Karl Goldmark 1830-1930: Additions to his Life and Works in Hungarian Context] (Budapest: Sárkány Nyomda Részvénytársaság, 1930), 15-18.
} 
informed performance of the actual piece. This is certainly true with regard to impacts of all (e.g. "Austro-German”, Baroque, Hungarian) styles on Goldmark's music. Research has direct effect on practice in this aspect. Therefore, how knowledge gained through research may inform interpretation of Goldmark's piano works is also a focus of my study.

My research will fill a gap in existing literature about Goldmark's piano music, promoting a more comprehensive understanding of a significant composer of $19^{\text {th }}$-century Vienna and a deeper knowledge of Vienna's cultural identities and musical landscape. My research will also contribute to a fuller picture of $19^{\text {th }}$-century "Austro-German", and in a broader sense, Romantic piano culture. According to Kecskeméti, Goldmark's piano works are equally important in his output as his operas and symphonic works, and they are undeservedly forgotten. ${ }^{51}$ I hope that my work will enhance the recognition of this overlooked composer who was internationally renowned in his lifetime, by introducing this undiscovered segment of his oeuvre. My work aims to fit in the revival of Goldmark's music - whose work deserves more attention - which was anticipated by Kecskeméti in the 1980s and can be sensed since then. ${ }^{52}$

\section{Forgotten Piano Music of Karl Goldmark}

\section{Abstract}

Karl Goldmark became an esteemed figure in Vienna's cultural life alongside Brahms and Hanslick, who recognized the distinctive qualities of his music. Whilst Goldmark's most popular works - for example Die Königin von Saba which earned world fame for him - were performed across Europe and America, his piano music remained almost completely undiscovered. This exploration aims to introduce that repertoire by placing it in the context of Romantic piano literature. This will not only add new perspective to existing scholarship but enhance a more complex understanding of a significant figure's music, linking different styles and eras.

${ }^{51}$ István Kecskeméti, (lectures on Goldmark’s music) Hungarian Radio, Budapest, 1980.

52 Kecskeméti,"Receptions," 34, 37. 


\section{Zapomenuté klavírní dílo Karla Goldmarka}

\section{Abstrakt}

Karl Goldmark se stal váženou postavou vídeňského kulturního života vedle Brahmse a Hanslicka, který rozpoznal nesporné kvality jeho hudby. Zatímco většina Goldmarkových nejvíce populárních děl - např́iklad skladba Die Königin von Saba, která mu zajistila světovou slávu - byla uváděna v Evropě i Americe, jeho klavírní odkaz zůstal téměř neznámý. Tento př́spěvek se snaží pojednat o tomto repertoáru v kontextu klavírní literatury epochy romantismu. Přináší nové perspektivy do existujících osnov vzdělání a přispívá také $\mathrm{k}$ ucelenějšímu porozumění Goldmarkově tvorbě.

\section{Keywords}

Austro-Hungarian; Karl Goldmark; piano music; Romantic; Vienna; forgotten; $19^{\text {th }}$ century.

\section{Klíčová slova}

Rakousko-mad’arský původ; Karl Goldmark; klavírní tvorba; romantismus; Vídeň; zapomenutý; 19. století. 